\title{
The Status of Sexuality in Neoplatonism
}

\author{
José María Zamora Calvo
}

(Autonomous University of Madrid)

\begin{abstract}
The stereotype of "Platonic love" that developed during the Renaissance implies a type of relationship, between two people of the opposite gender, which does not involve sexual activity. A new examination of certain relevant texts by Neoplatonists such as Plotinus, Porphyry, Hierocles, Hermias, Proclus and Olympiodorus, written during the period of Late Antiquity, establish that the question of sexuality is present in the very architecture of their systems, thus maintaining a coherent approach over time. "Mixed love", tending towards the sexual union that enables the conception of children, is morally good. Through an exegesis of the Symposium, Phaedrus and First Alcibiades, each of these Neoplatonic philosophers explores sexuality through the prisms of cosmology, ethics and political theory.
\end{abstract}

\section{Keywords}

sexuality; Neoplatonism; mixed love; Neoplatonic love; Neoplatonic ethic 
In the Life of Isidore, Damascius tells the story of the philosopher Theosebius (a disciple of Hierocles of Alexandria and an admirer of Epictetus), ${ }^{1}$ who was not able to have children and as a result, suggested to his wife that she should either swap her wedding ring for a chastity ring (i.e. become celibate), or marry another man. She chose a life of abstinence, and so the couple lived out the days of their marriage (with the help of this "talis-

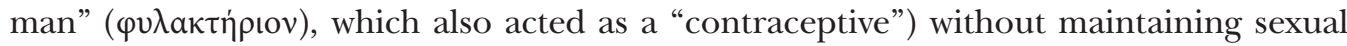
relations $\left(\right.$ Fr. 110.87.19-89.4 Zintzen $=$ Fr. 46E Athanassiadi). ${ }^{2}$ This story illustrates, with particular clarity, the Neoplatonic view of the purpose of marriage.

Three centuries earlier, in his treatise On Love (3.5), Plotinus (204/5 - 270 AD) considered sexual union, with its basis in nature, to be morally good (Wolters 1972: pp. xvi-xxii, n. 1). The desire for eternity gives marriage a moral value, as the procreation of new human beings is good in itself, since it represents an inferior and alloyed form of the desire for beauty. The manifestation of the intelligible world in the things of the

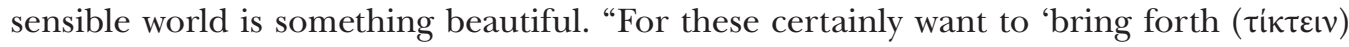
in beauty ( $\dot{\varepsilon} \vee \kappa a \lambda \tilde{\omega})^{\prime}$ : for it would be absurd for nature, when it wants to create beautiful things, to want to generate in ugliness ( $\dot{\varepsilon} v$ aio $\chi \rho \tilde{\omega})$ )" (Plot. 3.5.1.28-30; transl. Armstrong 1967: p. 169). Procreation allows us to see the immortal in what is mortal. Plotinus draws on Plato's Symposium (206c4-5) - "procreate in what is beautiful" - ${ }^{3}$ in order to affirm that mixed love (which is also a love of beauty) is fecund, although it corresponds to a desire for sexual union, rather than to a contemplative love. As such, mixed love wishes to procreate with a beautiful body.

For Plato, love is inseparable from fecundity and always begets children, whether physical or spiritual; for Plotinus, however, only mixed love is fecund: in other words, love and fecundity are not necessarily connected, given that only biological procreation arising from sexual union is fecund. ${ }^{4}$ Therefore, the pure love of bodies is not sexual; rather, it is solely and exclusively contemplative. Nonetheless, as Plotinus explains, the desire for fecundity can be based on the desire to imitate the relationship between the eternal and the beautiful, in light of the fact that the eternal nature of intelligible forms, which is identified with the primary Beauty in the strictest sense of the term, and everything that proceeds from it, is beautiful (Plot. 3.5.1.44-46; see also 1.6.9.34-42). As such, fecundity aims to imitate eternity through the perpetuation of the generations.

1 Damascius described him as the Epictetus of his era; indeed, Theosebius considered Epictetus to be a Platonist, rather than a Stoic (Dam. V. Isid. Fr. 109.85.14-87.17 Zintzen = Fr. 46D Athanassiadi).

This paper benefited from the support of two Spanish R\&D projects: "Lecturas neoplatónicas sobre la inmortalidad del alma: de Plotino a Damascio" (Ref. HAR2017-83613-C2-2-P) and "Pensar las emociones en la Atenas democrática: diálogo entre la comedia y la filosofía (Pathe) - Programa Logos Fundación BBVA de ayudas a la investigación en el área de Estudios Clásicos 2019", and is part of the activities of the UAM Research Group: Influences of Greek Ethics on Contemporary Philosophy (Ref. F-055). I thank the anonymous referees who kindly reviewed this paper and provided valuable suggestions and comments.

2 Regarding the position occupied by Theosebius in the Neoplatonic school of Alexandria, see e.g. I. Hadot (2015: pp. 3-5) and Goulet (2016: pp. 1128-1129).

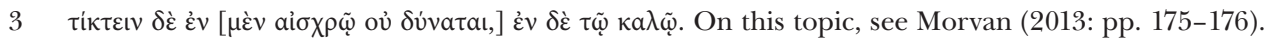

4 See e.g. Armstrong (1967: p. 170, n. 1), and Hadot (1990: pp. 27-28). 
Love, whether of a moderate or perturbed nature, is born out the desire for beauty itself before anything else (Plot. 3.5.1.20-26; see Hadot 1990: p. 151). Plotinus alludes to the myth of Phaedrus (249d-250b): the soul, as it has already known the essence of beauty during its previous existence, is able to recognise it through memory, in the image of sensible beauty; thus, the memory of true beauty gives wings to the lover.

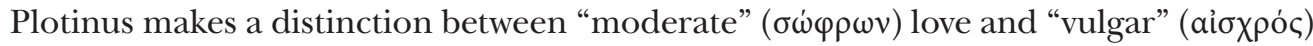
love (Plot. 3.5.1.13-14). In the Platonic tradition, the adjective aio 0 pó $\varsigma$, which is opposed

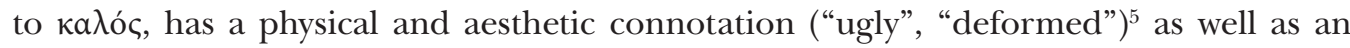
ethical and civic one ("shameful", "vile", and also "disgraceful", "ignoble"). ${ }^{6}$ In his treatise On Beauty, Plotinus states that aioxpó (Plot. 1.6.5.23-58), ${ }^{7}$ referring to a form of sexual union that implies shame, is nothing more than an adventitious event in the life of the soul. However, this "vulgar" ${ }^{8}$ act is not specifically related to homosexuality; ${ }^{9}$ rather, it can be applied to all sexual practices. As such, the term implies a moral reprobation.

There can be no fecundity or procreation in what is "vulgar" or "shameful", as the concepts are dissonant. For Plotinus, fecundity and procreation refer to the idea of "nature" ( body during procreation. Sexual activity that conforms to nature must take the corresponding limits into account, in order to avoid deviating from its course.

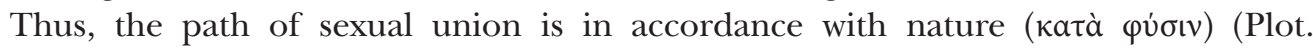
3.5.1.42). The love that wishes to procreate and is related to sensible beauty, provided it remains moderate, is not morally reproachable; ${ }^{10}$ however, an immoderate sexual union may result in moral failure. "If they remain moderate ( $\sigma \dot{\omega} \varphi \rho \circ \sigma)$ ) there is no error

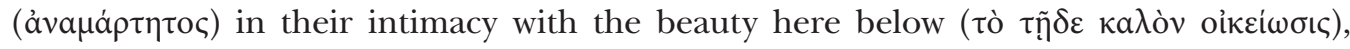

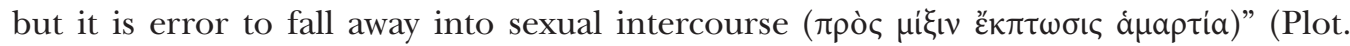
3.5.1.36-38; transl. Armstrong 1967: p. 171, slightly amended). Here, "immoderate" corresponds to an unchecked appetite for pleasure, which ignores procreation and therefore deviates from what is "natural". Moral failure disfigures love and transforms it into

5 See Pl. Smp. 211a3. Beauty lies in measure, proportion and symmetry, which are also the qualities that pertain to what is beautiful and what is good; or the qualities that they present, according to Philebus

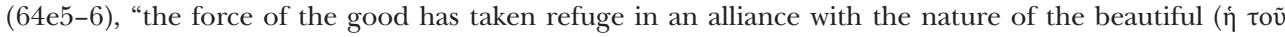

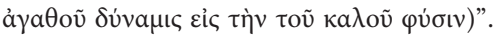

6 See Pl. Ap. 28c3, 28c9; and DGE s.v. A and B.

7 On the meaning of aioxpóc, see DGE s.v., and Dover (1979: p. 159). For Plotinus, ugliness is not

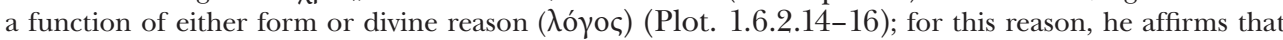
matter is ugly in itself, and not just by accident (Plot. 3.6.11.27). Thus, an examination of ugliness must be conducted in parallel to that of evil (Plot. 1.6.6.22). Indeed, matter is identified with evil and primitive ugliness (Plot. 1.8.5). The formula of kakos kaischros corresponds to matter (ü $\lambda \eta)$, to non-being, the final link in the processional chain; in contrast, being, form and beauty all coincide in Intelligence. However,

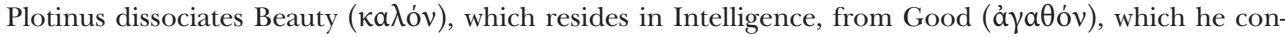
nects to the One, the first principle that lies beyond beauty and the intelligible. True beauty is only the sign or trace of the One. On ugliness in Plato and Plotinus, see Aubry (2013: pp. 34-37, 45-46).

8 In a sense close to $2 D G E$ "obscene".

9 Plotinus criticises the Gnostics for their disorderly approach to sex, in terms of the education of young people and with regard to women more generally (Plot. 2.9.17.28).

10 Every production, and every action, is a weakening of contemplation (Plot. 3.8.4.31-47). 
something vulgar and shameful, as it prevents those who commit it from recognising ideal beauty and cuts them off from its memory.

Moderate love, if it does not deviate from its path, implies the sexual union that is

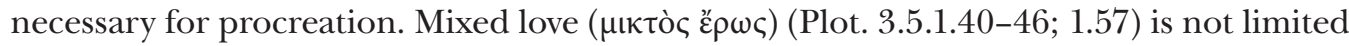
to contemplation of the beautiful: it also desires beautiful bodies and to procreate with the beautiful bodies that it desires (Pl. Smp. 206e8). Consequently, it is not satisfied with the simple contemplation of beauty; it also needs to (re)produce (itself) in a beautiful object. ${ }^{11}$

However, this mixed love can become deviated and abandon the path marked out by nature (Plot. 3.5.1.50-55). The intense pleasure of sexual union can bring about this deviation in the lovers' primary aim (Plot. 3.5.1.38), even causing them to wish to procreate in a manner that is against the law and against nature. ${ }^{12}$ In a sexual relationship that is in accordance with nature, pleasure is only an accompaniment to the sexual act; it is neither its purpose nor its guiding force. The key to ensuring mixed love remains moderate, and remains on the path marked out by nature, lies in controlling pleasure.

Following an initial bipartite classification (Plot. 3.5.1.12-14), Plotinus establishes several categories for lovers of sensible beauty, in accordance with the following quad-

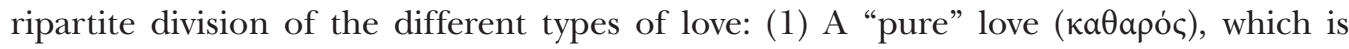
removed from the sexual union of bodies and pertains to the "moderates", and may (1a) accompany or (1b) may not accompany the reminiscence of transcendent Beauty. (2) A "mixed" love, which tends towards sexual union and pertains to the "immoderates", and (2a) may be in accordance with nature and remain on the path of moderation (heterosexual), or (2b) may be against nature (homosexuality and sexual deviance).

Mixed love, involving sexual union that enables the conception of children, is morally good. Consequently, sexual union "in accordance with nature" may be viewed from two perspectives (2a) and (2b): "But, to return to the point, (1) those who love beautiful bod-

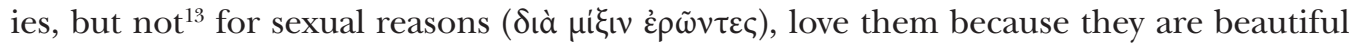

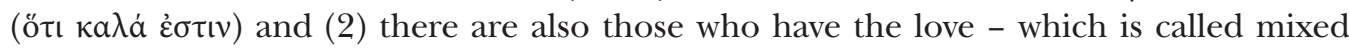

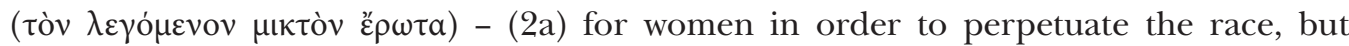
$(2 \mathrm{~b})$ if it is love for other than women they are making a mistake ( $\sigma \varphi \alpha \lambda \lambda$ ó $\mu \varepsilon v o \iota)$ " (Plot. 3.5.1.55-59; transl. Gerson: 2017: p. 294; see also Igal 1985: p. 124).

11 In $L g$. (8.838e-839d), Plato lists a series of practices that deviate from nature.

12 "But those who want to generate illicitly and contrary to nature (Oî $\delta$ ' àv $\dot{\varepsilon} \theta \dot{\varepsilon} \lambda \omega \sigma \mathrm{l} \gamma \varepsilon v v \tilde{a} v)$, take their start on the natural course, but as they begin to veer off-course, lie there in collapse as though they had slipped off the proper road, without understanding where love has led them or their desire for generation or the right use of beauty's image or what beauty is in itself" (Plot. 3.5.1.50-55; transl. Gerson 2017: p. 294). Here, Plotinus uses the plural "those who" (Oî $\delta$ ' äv) to refer to the lovers "who wish to generate" in an "illegitimate manner" that is "outside the law" ( $\dot{\varepsilon} v$ rapavó $\mu \omega)$ and "against

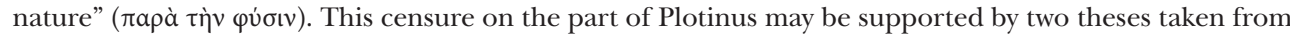
Book VIII of the Laws, in which Plato condemns all sexual practices that do not contribute to legitimate conception (homosexuality, incest, sodomy, onanism). See Brisson \& Pradeau (2006: p. 321, n. 67).

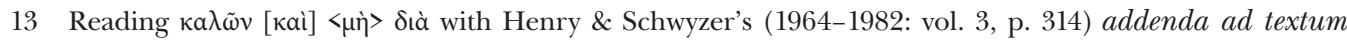
following Ficino's original emendation. See Igal (1985: p. 118), and see also Gerson (2017: p. 294, n. 12). 
Through procreation, man finds a way to make himself part of the cosmic totality (Morvan 2013: p. 178), and performs - on Earth - a task that forges a link between mortals and the gods. Instead of an áváßaoıs, which seeks to replace the gods, procreation

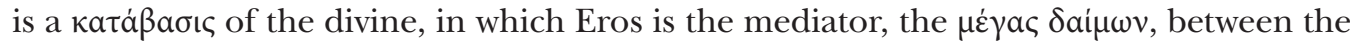
mortal and the immortal. Mixed love is fecund, and sexual union ensures the continuation of the generations.

Plotinus's reproach is directed specifically at those who deviate from their natural course, as though they were straying from their path: in other words, at a certain point they deviate from their route by moving in a direction that takes them away from a path they had initially embarked upon correctly. Later, Plotinus indicates that the loves that

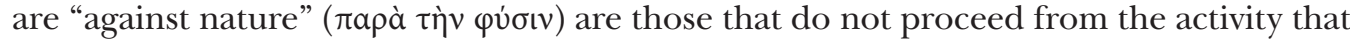

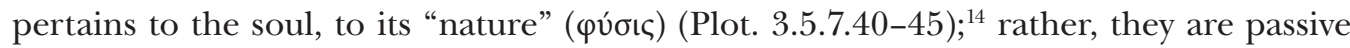
affections, produced by an entity that is not of the soul and which is identified with vice,

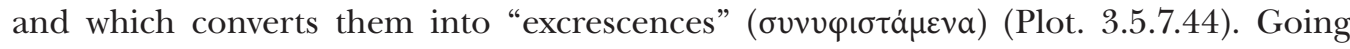
against the nature of the soul means seeking physical pleasure instead of intelligible beauty, as the disordered inclination of the soul towards matter results in the creation of vice. In fact, for Plotinus, the Gnostics deviated from the interpretation of Timaeus, and this dissociation led them to engage in sexual practices that were against nature.

Marcella was a rich widow and the mother of five daughters and two sons. Her second marriage was to Porphyry (223/4 - c.305 AD), who dedicated the Letter to His Wife Marcella to her after the couple had lived together for just ten months (Porph. Marc. 4.106.23). At the start of the letter, Porphyry justifies their marriage, which had undergone a series of slanders at the hands of Marcella's fellow citizens and even caused her to fear for her life (Marc. 1.104.18-105.3) with recourse to the following "two honourable reasons": (1) the "gods of birth", ${ }^{15}$ and (2) coming to the aid of a friend's widow and her children, in light of the fact that Marcella demonstrated a "natural aptitude for true

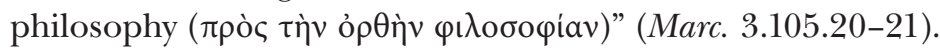

In the anthropology of the early Neoplatonists, the body is not considered to be an integral part of man: consequently, sexual activity is blocked by the movement of an ascesis that is hostile to the notion of contact between bodies. Porphyry, who wrote the letter to his wife while he was travelling, ${ }^{16}$ and in order to console her while she was suffering during his temporary absence, told her that the true Porphyry cannot be, for her, the one who touches her; rather, he is the one who transcends the senses and is only captured by thought (Marc. 8.110.3-7; see also 32.124.20-21). Thus, the body is nothing more than an "image" or a "reflection". Porphyry tries to make his wife understand that,

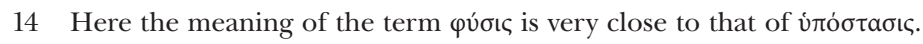

15 The gods of family and race are also the "gods of birth" (Pl. Lg. 5.729c7) or "those who preside over procreation” (Lg. 9.879d2). See Des Places (1982: p. 157, n. 2).

16 Some have speculated that Porphyry was asked by the emperor Diocletian to travel to the East in order to take part in a preparatory meeting ahead of the great persecution of the Christians that took place in the year 303. However, if we take the testimony of Lactantius (De mortibus persecutorun 11.3 and 6), into account, this hypothesis presents certain difficulties. See Goulet (2004: p. 101). 
in the movement of an ascesis that is hostile to contact between bodies, it does not not matter if he is with her physically.

The human soul can ascend and return to its origins, or travel downwards and become submerged in oblivion. ${ }^{17}$ The first status of the soul, symbolised by Poros, corresponds to the conversion to the intelligible; the second, symbolised by Penia, corresponds to the conversion to the sensible. ${ }^{18}$ In On the Cave of the Nymphs (16), Porphyry connects the two mythical episodes that link honey to the "red nectar" consumed by the gods: (1) the speech given by Diotima in Plato's Symposium (203b), in which Poros is saturated with nectar; and (2) the Orphic motif that alludes to the intoxicating power of honey (OF 189 $\mathrm{K}=221 \mathrm{~F}$ Bernabé). Honey is related to drunkenness and sleep. ${ }^{19}$ In Orpheus, honey causes Kronos to fall into Zeus's trap, who is thus able to bind and castrate him.

Honey possesses three qualities: (1) purification, ${ }^{20}(2)$ preservation, and (3) sweetness (Porph. Antr. 15). Porphyry associates the third quality, sweetness, with sexual union. ${ }^{21}$ In fact, according to Simonini's (1986: pp. 163-164) interpretation, the section dedicated to the sweetness of honey and its association with sexual pleasure refers to the soul's descent to the body and its consequent loss of autonomy by becoming embodied. Sexual pleasure prompts the divine beings to spread their seed, in order to disseminate their power of generation. To describe this dissemination on the part of divine beings, Porphyry employs astronomical terminology: the sphere of Saturn (Kronos) occupies the primary position opposite Ouranos, the heaven of fixed stars, followed by the sphere of Zeus. Thus, the divine powers are transmitted from Ouranos to the sphere of Zeus by way of the sphere of Kronos.

"That is, right here in this world the breath ( $\tau$ ò $\pi v \varepsilon \tilde{v} \mu \alpha$ ) becomes damp or saturated, as a function of its sexual desire, and the soul drags a damp vapor along with it from its descent toward generation" (Porph. Antr. 11.18-20; transl. Lamberton 1983: p. 28, slightly amended).

The souls that descend during generation are associated with water, which implies their true death;22 pure souls, in contrast, avoid generation, and only they are wise. In order to confirm this association, Porphyry draws upon Heraclitus: "A dry soul

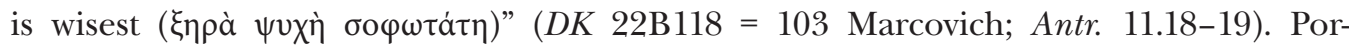
phyry describes the descent of the souls as a process in which their "breath" ( $\pi v \varepsilon \tilde{v} \mu \alpha)$ becomes heavier due to the absorption of moisture. Upon completion of the descent, this enlargement of the breath makes the souls more "visible" (ópataí). Certain souls do not manage to master their breath, and are instead dominated by it, becoming

17 See Porph. Sent. 3, 4, 28, 30 and 32; Orac.Chald. Fr. 172 Des Places.

18 Hadot (1968: pp. 90-91, n. 1) draws a parallel between Porph. Abst. 3.27, and Sent. 37 and 40.

19 See $O F 154 \mathrm{~K}=220 \mathrm{~F}$, 222 F Bernabé; $O F$ 137, 154, $220 \mathrm{~K}=225$ F Bernabé.

20 See Arist. HA 4.535a1-3; 8.596b15-18. In Porph. Antr. 15 and 19, honey, which is used in the ritual, symbolises the moral purification that guarantees the initiation.

21 See Porph. Antr. 16.249-257. See Giavatto (2019: pp. 206-208).

22 Ficino translates it as lux sicca. Philo of Alexandria attributed this formula to Heraclitus in order to define the best and wisest soul. For the soul, death consists of becoming "wet"; see B $77 \mathrm{DK}$. 
absorbed by its passionate aspects; other souls, in contrast, draw support from their breath and are able to master it. ${ }^{23}$

According to Damascius's Life of Isidore (Fr. 54.80.1-11 Zintzen), Hierocles (c.1st half 5 th century AD) taught philosophy in Alexandria, where his pupils included the aforementioned Theosebius. ${ }^{24}$ Hierocles's philosophical architecture lies within the sphere of Neoplatonism, between the approaches of Iamblichus and Syrianus - Proclus (I. Hadot 2015: pp. 99-124). He dedicated his treatise On Providence and Fate and the Relationship of Free Will to Divine Governance to the diplomat Olympiodorus, who had a passion for philosophy and possessed his own "political philosophy": he successfully participated in a number of Roman embassies, which brought him significant honours. ${ }^{25}$ Of the original seven-volume treatise, only a few fragments remain, in the form of two short summaries written by the patriarch Photius $(c .815-c .897)$ in codices 214 and 251 of his Myriobiblion. ${ }^{26}$ One of the sections of this treatise explores a subject that is of particular interest to our study. In the distinction that is made by Plato in Phaedrus (248a-249b), Hierocles

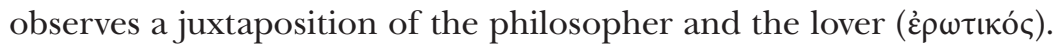

The "philosopher" dedicates himself to a life of contemplation, avoiding political activity and purifying himself in the search for union with the divine; the "lover", in contrast, is identified with the philosopher-king of Plato's Republic $(5.473 \mathrm{c}-\mathrm{d}$; 501e-502c; see also Ep. 7.326a2-b4), who communicates the intelligible good to others, shapes the city in accordance with paradigms of the divine, just and beautiful, and thereby applies contemplative intelligence to the sphere of political action. ${ }^{27}$ In this juxtaposition Hierocles delves deeper into the equivalence of the philosopher and the lover, in light of the fact that in the contemplative life of the former, the focus and pull towards an individual way

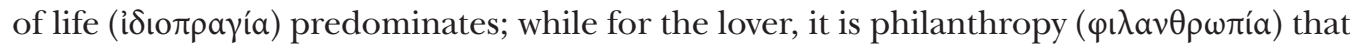
predominates (Hierocl. Prou. 465a [t. VII, p. 202 Henry]).

Thus, Hierocles articulates the Plotinian distinction between the contemplative union with the One and the political expression of this union (Plot. 6.9.7). However, although Hierocles clearly defends the superiority of the contemplative union, in line with the thesis of Neoplatonism, he takes an innovative approach with his support for the "lover", whom he identifies with the philosopher-king. The extrinsic value of the life of the lover - philosopher-king, which is linked to philanthropy, balances out the intrinsic value of the contemplative life. Thus, Hierocles's philanthropy makes it possible to communicate the fecundity of the transcendent Good to another, through the mediation of the lover - philosopher-king (O’Meara 1993: pp. 69, 72). From its first Plotinian articulation,

23 Porph. Abst. 2.38.2 and 4. These two types of soul correspond to the duality of good and evil demons. For terrestrial life, including plants, moisture is necessary (Antr. 10.19-20).

24 See also Dam. V. Isid. Fr. 106.83.1-4; 56-59.82 and 84 Zintzen.

25 See Phot. Bibl. cod. 214.171b22 ff. (t. III, p. 125 Henry). It is most likely Olympiodorus of Thebes, an Egyptian historian who was part of a diplomatic mission to the Huns in the year 412 (cod. 80.58b37; t. I, p. 173 Henry).

26 Phot. Bibl. cod. 214 (t. III, pp. 125-130 Henry), and cod. 251 (t. VII, pp. 189-206 Henry). See Aujoulat (1996).

27 Hierocl. Prou., ap. Phot. Bibl. cod. 251.464b (t. VII, p. 200 Henry; ed. R. Henry, VII, Paris, 1974, p. 200). 
the Neoplatonic metaphysical principle, expressed in its medieval formulation as bonum est diffusivum sui, ${ }^{28}$ indicates that all of reality unfolds in a series of levels from the absolute perfection of the One-Good, which is the first principle and absolute power of all things (Plot. 5.4.2.37-43). ${ }^{29}$ For Proclus, certain souls, having shared the transcendent good in the divine life, imitate the Good by attempting to communicate the good to inferior beings. ${ }^{30}$ Thus, in order to describe the contemplative involvement of the transcendent Good that infuses a movement of communication of the good to others, Hierocles adopts the terminology of eroticism, in which the lover is the philosopher-king of Plato's Republic (5.473b-d; 502c; see also Ep. 7.327a-340a).

In the 5th century AD, Hermias of Alexandria, who studied alongside Proclus (412485) at the Neoplatonic school in Athens, wrote a commentary on Phaedrus based on his notes from a seminar that his master, Syrianus (d. 437?), had given on the subject of Plato's dialogue. ${ }^{31}$ Hermias's commentary is the only exegetical study of Phaedrus from Antiquity that has survived through to the present day. ${ }^{32}$

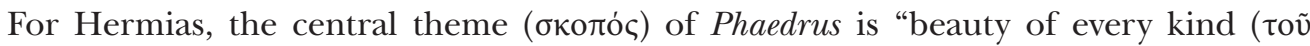

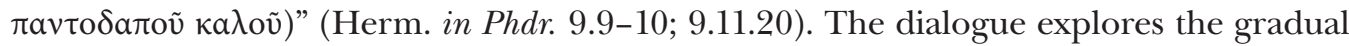
ascent to true Beauty, from the lower level (corporeal beauty), up through the beauty of speech, and towards the beauty of the soul, finally ascending to intellectual beauty. In his exegesis, which follows the Neoplatonic rules of interpretation established by Iamblichus, Hermias connects these three dialogues hermeneutically: Phaedrus, Symposium and First Alcibiades.

In his Commentary on Plato's Phaedrus, Hermias also examines the problem of sexuality. The demonology of Middle Platonism was still present in Neoplatonism, albeit interpreted according to hermeneutic rules and the doctrinal principles of the post-Plotinian approach (Moreschini 2017: pp. 132-135). However, in his exegesis, Hermias (Syrianus) highlights the role played by demons in transmitting enthusiasm from the gods to the irrational faculties of the soul (Herm. in Phdr. 85.14-21; see Lortie 2017: pp. 216-218).

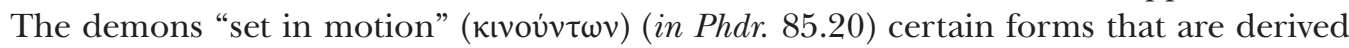
from enthusiasm and, ultimately, originate with the gods, thereby illuminating both the intellective faculty (voṿ) and the other faculties of the human soul: discursive thought

28 The One-Good, beyond the intelligible (Plot. 5.1.8.7-8; 5.3.11.28; 6.8.11.8-9). On this principle of Neoplatonic metaphysics, see Kremer (1987).

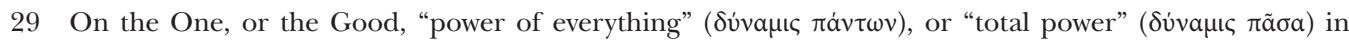
Plotinus, see Zamora Calvo (2016).

30 Procl. De malorum subsistenita 23 (Isaac 1982: p. 58); see O’Meara (2003: pp. 209-210).

31 Dillon (1994: p. 388): "Hermeias is really just transcribing the proceedings of his master Syrianus' seminar". See also, Westerink \& Trouillard \& Segonds (1990: p. X): "Le Commentaire du Phèdre que nous possédons sous son nom n'est qu'un ensemble de notes non révisées prises au cours de Syrianus sur ce dialogue". Regarding this commentary on Plato's Phaedrus we have the edition by Lucarini \& Moreschini (2013), which replaces the only earlier critical edition (Couvreur 1901) and includes complete indices. There is also a version in Romanian, accompanied by a translation of Plato's Phaedo and Phaedrus by Lijceau \& Cornea \& Bercea (1983); a German translation by Bernard (1997), and a recent English translation by Baltzly \& Share (2018).

32 Baltzly \& Share (2018: p. 1): "Hermias'commentary on the Phaedrus of Plato is the only example of the Neoplatonic commentaries on this dialogue to have survived in it entirety". 


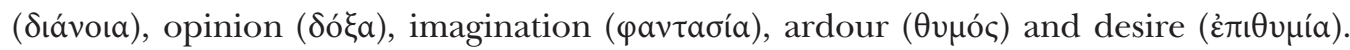
Thus, the demon plays a providential role, as it guides the destiny of man, i.e. a soul that makes use of a body, extending its activities to encompass faculties that are, strictly speaking, human, whose highest point is reason and whose extremes correspond to sexual desires, which are included in the nutritive-reproductive faculty.

Hermias defends the elevatory power of the Socratic eros, along with the image of Socrates as a divinely inspired teacher. Roskam (2014) demonstrates that, in Hermias's commentary on Phaedrus, Socrates is portrayed as an ideal teacher whose aim is to elevate the soul to the intelligible world, beyond the corporeal world of sensible pleasures. Thus, for Hermias, Socrates is a contemplative philosopher who highlights the need to ascend to the divine and achieve consequent purification.

In his reading of the Socratic eros, Hermias banishes the concept of corporeal love. In his interpretation of Phaedrus, he applies a methodology in which the Symposium provides him with a panoramic perspective of eros $^{33}$ and First Alcibiades provides him with a specific perspective on knowledge itself and the strategics of purification. From this hermeneutic perspective, Hermias suggests that although they may reject corporeal pleasure, lovers can still come together and maintain sexual contact, provided it remains moderate and controlled. For Hermias, even though a true lover may touch his beloved, he always does so with self-control (Herm. in Phdr. 201.13-14).

The exegetic methodology Hermias employs in his commentary on Phaedrus shares certain traits with Proclus's Commentary on the First Alcibiades. In fact, from this hermeneutic perspective, Phaedrus is linked to self-knowledge, which constitutes the purpose or central theme (бколо́ $)$ ) of the dialogue. However, this purpose, which is linked to the practice of the Neoplatonic exegetical method, occurs over the course of the dialogue, at the end of the demonstrations that themselves include a second purpose: that of "selfcare". Thus, Proclus assigns a central position, or an ultimate purpose, to the idea of "self-care", to which he subordinates the idea of "self-knowledge". The Delphic precept is accompanied by a specific ethical usage, of an eminently practical nature. Without self-knowledge, there can be no self-care.

Dillon (1994) shows how, through their commentaries, the Neoplatonists - and especially Proclus - view the First Alcibiades as a kind of ars amatoria oriented towards the practising of a true and shared form of love. Consequently, from this perspective, the dialogue serves a preliminary function, as the purpose of the encounter lies in a practice - that of "true eroticism" - that is no longer based on the exchange of words, but on a sexual exchange, i.e. the union between the lover and his beloved. "This, then, may be

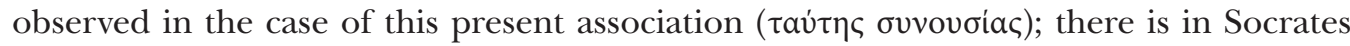

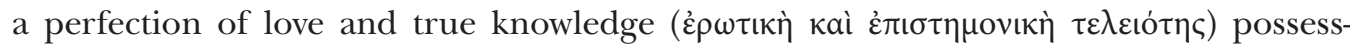
ing a ready beneficence towards his beloved, and there is in Alcibiades a suitability for

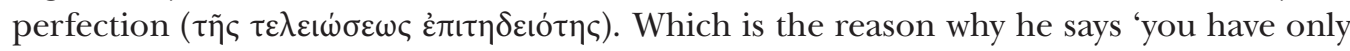

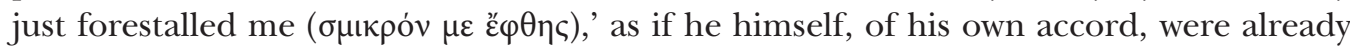

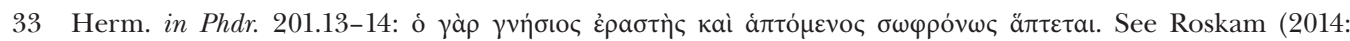
pp. 32). Bernard (1997: p. 24-25) suggests that Hermias interprets Phaedrus through the prism of the Symposium. 
stirred towards Socrates" (Procl. in Alc. 123.17-124.2 Westerink; transl. O’Neill 1971: p. 81).

For Proclus, the erotic science provides the intermediary force of communication. Without it, it is not possible to communicate the Good or achieve (intellectual) union with the divine. The exchange between teacher and pupil is a form of communicating the Good.

Eroticism serves as a guide, moving words into the background in order to allow the union to communicate the Good. In his Commentary on Plato's Republic (Essay 6), Proclus offers a mythological interpretation of the sexual union between Hera and Zeus: it is a mythological representation of the loves of the gods "concerned with reversion of the

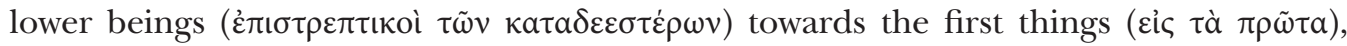
and with filling (åmо $\pi \lambda \rho \omega \tau$ เ themselves, and with bringing to perfection those lower than themselves ( $\tau \varepsilon \lambda \varepsilon \sigma i o v \rho \gamma o i$

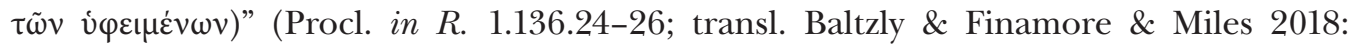
p. 250). ${ }^{34}$ Thus, union enables communication of the Good.

However, in order for this communication to occur, there must be a place that facilitates the union (Procl. in Alc. 123.8-9); "and in some way the perfection of the giver must coincide with the suitability of the recipient" (in Alc. 123.10-12; transl. O'Neill 1971: p. 81). Consequently, there are two conditions that must be met: (1) on the part of the giver, there must be perfect power, a "superabundance"; and (2) the recipient must be well-disposed to receive. Likewise, in order for communication of the good to occur, three conditions must be met: (1) the "opportune moment" (кaıрóৎ) for each activity, "as supplying the good and the ultimate purpose to the doers and to what is actually being done" (Procl. in Alc.121.18-20); (2) this moment must proceed from the divine beings, it cannot be the product of random chance; and (3) the perfection of the giver must coincide with the suitability of the recipient: the giver must possess a "perfect power", a "superabundance" of good, while the recipient must be well-disposed to receive (in Alc. 123.1-13). Socrates's "erotic and scientific perfection" is the driver of the communication that enables the sharing of the same place, which is in fact necessary given that the cause is corporeal (Van der Meere 2017: pp. 258-259).

In his Commentary on the First Alcibiades (34.16-36.20), Proclus, while examining the qualities that distinguish the "divine $(\theta \varepsilon \tilde{c}$ ऽ) lover" from the "vulgar and coarse lover

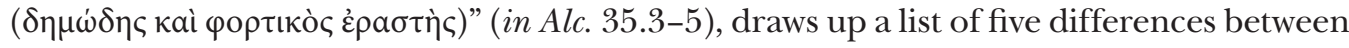
these two types of lover. Subsequently, in the 6th century, Olympiodorus of Alexandria (in Alc. 13.12-14.9; and in Grg. 135.22-24) condenses Proclus's classification into three

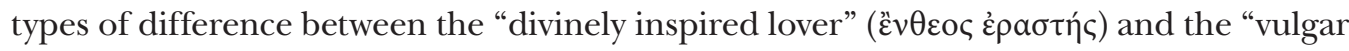
lover" ( drus (238e1-240a8): (1) The vulgar lover admires the object of his loves, while the divine lover is the one who is admired. ${ }^{35}$ (2) The vulgar lover moderates his love as his beloved

34 See also Procl. in R. 2.296.21-27: the soul "joins with the first terms".

35 According to Olympiodorus, this interpretation is found in the expression: "Son of Kleinias, I think you admire", which Olympiodorus takes to mean "I think you admire me" (= Procl. in Alc. 35.6-13). See Segonds (1985-1986: vol. 1, p. 144, n. 5). 
grows older, and soon distances himself from the object of his loves; the divinely inspired lover, however, accompanies the object of his loves "from the cradle to the grave". ${ }^{66}$ (3) The vulgar lover is present in his loves and wishes to act in accordance with the sensations of the body, and in particular to employ the last of the senses, i.e. touch (as he desires to touch); in contrast, the divinely inspired lover engages in an exchange with his

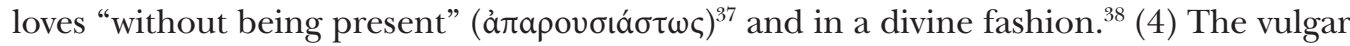
lover is present in his loves in order to bring them to ruin, in terms of body, soul and the exterior good; however, the divinely inspired lover does not act in the same way, and nor does he pursue the same goals: rather, he is present in his loves for their own good, as he directs them towards beautiful objects (Olymp. in Alc. 14.4-9). ${ }^{39}$

Regarding the fourth difference between the two classes of lovers, which corresponds to Olympiodorus's third category, Proclus notes that the divinely inspired lover accom-

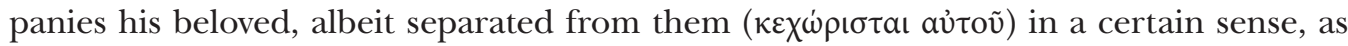

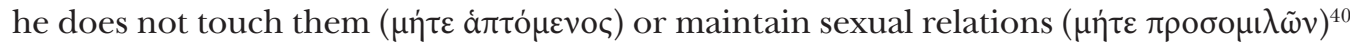
with them, or even converse with them ( $\mu \dot{\eta}^{\prime} \theta^{\prime}$ ö $\lambda \omega \varsigma \delta\llcorner\alpha \lambda \varepsilon \gamma$ ó $\mu \varepsilon v o \varsigma)$ until the opportune moment (каıрó) arrives in which to do so (Procl. in Alc. 36.4-7 Westerink); in contrast, the vulgar lover "loves to unite with his beloved" (Segonds 1985-1986: vol. 1, p. 29).

For Proclus, true love means the love of what is beautiful. ${ }^{41}$ As the good lies beyond the beautiful, it can only arouse desire in us, not love. ${ }^{42}$ The starting point is the same passage from Plato's Symposium (210a4-211c9) that Plotinus uses (1.6.4.7-9; 5.2-5; 9.36). ${ }^{43}$ Adhering to a hermeneutic strategy that will be found also in Olympiodorus (in Alc. 119.4-6), Proclus constructs the following syllogism: "so if ( $\varepsilon \dot{\imath}$ oṽv) all the good is

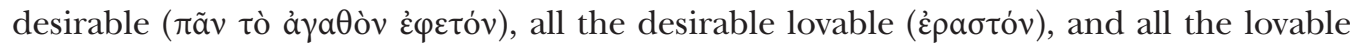

36 This difference is highlighted in the phrase: "Having been the first lover, while the others have given up; I am the only one who has not withdrawn". In other words: "that he follows the object of his loves before the other lovers, at the same time as them, and after them" (= Procl. in Alc. 35.13-24).

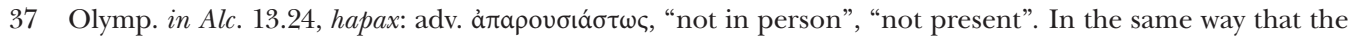
divine is present in all parts, illuminating even though it is entirely absent (in the sense that it is not in any particular place), the divinely inspired lover is both present and absent, in imitation of the divine.

38 In the passage: "While the others were disagreeable to you, I, throughout all those years, did not address you"; or in other words, "with his silence, he established a distance; however, by providing love and companionship, he was present" (= Procl. in Alc. 36.5-11).

39 See the corresponding passage in Phaedrus (238e1-240a8) that is taken as a reference (or serves as inspiration) to define this fourth difference that is not included in Proclus's commentary.

40 Here, the term $\pi \rho \circ \sigma \circ \mu \lambda \tilde{\omega} v$ not only means "associate", but may also mean "maintain sexual relations" (LSJ s.v.). In any case, in this passage it cannot simply mean "converse", as becomes clear in the text that

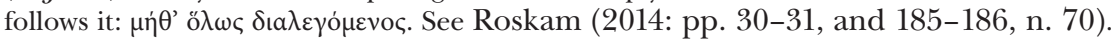

41 See Procl. Theol.Plat. 1.25.109.10-16. See Segonds (1985-1986: vol. 2, p. 455, n. 4).

42 See Plot. 1.6.9.32-43; 1.6.7.12-14.

43 "Conversely: all the good is desirable (this is self-evident), all the desirable is lovable (love and desire have

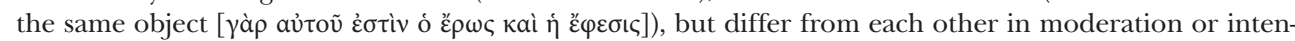

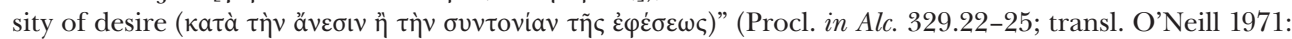
p. 216). On the difference between love ( $\left.\varepsilon^{\prime} \rho \varsigma\right)$ and desire ( $\left.\varepsilon \varphi \varphi \sigma \varsigma\right)$, see Dam. in Phil. 16.18-21. Proclus bases his argument on a passage from Plato's Symposium (204b3), in which Socrates elevates love up to the level of the good through the mediation of the beautiful, and states that the good is an object of love, as well as the beautiful. 


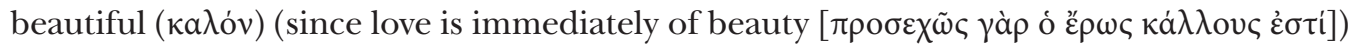

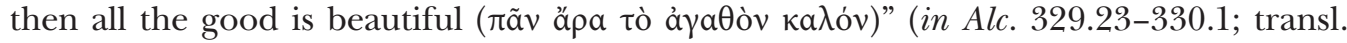
O’Neill 1971: p. 216).

Hermias's commentary on Phaedrus, as well as Proclus's and Olympiodorus's commentaries on First Alcibiades, offer a coherent image of the Socratic eros and of sexuality, based on an innovative exegesis of the Platonic dialogues and providing a hermeneutic connection to Phaedrus, Symposium and First Alcibiades. The three commentaries emphasise the elevatory power of the Socratic eros.

Sexuality in Neoplatonism is far removed from what is habitually referred to as "Platonic love" as defined in the Collins English Dictionary (Anderson \& Butterfield \& Crozier 2006: s.v. 2) "(usually lc) an intimate companionship or relationship, esp. between two persons of the opposite sex, that is characterized by the absence of sexual involvement; a spiritual affection". Although the concept of "Platonic love" was developed during the Renaissance by Basilios Bessarion (c.1403-1472) and Marsilio Ficino (1433-1499), ${ }^{44}$ a number of passages in Plato's dialogues recommend abstaining from sexual relations within a truly loving relationship.

The Neoplatonists explore sexuality through the prisms of cosmology, ethics and Platonic political theory; specifically, they construct their arguments on the basis of an exegesis of the Symposium, Phaedrus and First Alcibiades. This exegetic innovation enables them to balance the confrontation between purely intellectual love and desire of a strictly sexual nature. In this respect, for some Neoplatonists the "Platonic eros" is a larger whole that incorporates sexuality within it. Indeed, if we examine the texts on love that were written by the Neoplatonists during the period of Late Antiquity, from the founding of the movement in Plotinus's school in Rome during the 3rd century, through to the final classes taught by Olympiodorus at his school in Alexandria in the 6th century, we find that all of them consider the cosmos to be an image of an intelligible model. It is not possible to talk of sex without understanding the architecture of the intelligible universe and its projection in the sensible world. For the Neoplatonists, cosmology provides a model for ethics and politics: sex cannot be dissociated from the cosmos, and sexuality cannot be dissociated from cosmology.

44 In the Platonic circles of Renaissance Florence, Bessarion and Ficino developed an interpretation of Greek love as a type of spiritual practice. According to Bessarion (1503), Platonic love is the love that is "honourable, modest, demure, loyal, holy, blessed, a safeguard of chastity and continence, generously inspiring the soul and loving and obedient to virtue" (In Calumniatorem Platonis 4.2). In his commentaries on the Symposium and Phaedrus, Ficino explores this allegorical exegesis of Greek love that was instigated by his teacher, Bessarion, and repositions the discussion of "Greek love" within a broader discussion on the subject of "divine love". This metaphysical form of love is far removed from any earthly passions related to sexuality. See e.g. Blanshard (2010: pp. 27-28). 


\section{Bibliography}

Adrados, F. R. (Ed.). (1980). Diccionario griego-español (DGE) (Vol. 1). Madrid: CSIC.

Anderson, S., Butterfield, J., \& Crozier, J. (Eds.). (2006). Collins English Dictionary (8th ed.). Glasgow: HarperCollins.

Aujoulat, N. (1996). Sur le début du De providentia d'Hiéroclès d'Alexandrie: Photius, Bibliothèque, Codex 251, 460 b, 24-461 a, 22. Byzantinoslavica, 57(2), 217-228.

Armstrong, A. H. (Transl.). (1967). Plotinus, III: Enneads III. 1-9. London - Cambridge, Mass.: Heinemann - Harvard University Press.

Athanassiadi, P. (Ed.). (1999). Damascius: The Philosophical History. Athens: Apamea Cultural Association.

Aubry, G. (2013). (Comment) les Grecs ont-ils pensé la laideur?. In J.-J. Duhot (Ed.), L'archaïque, le réel et la littérature. Quelques chemins en hommage à Gilbert Romeyer Dherbey (pp. 33-46). Lyon: J. André.

Baltzly, D., Finamore, J. F., \& Miles, G. (Transl.). (2018). Proclus. Commentary on Plato's Republic (Vol. 1: Essays 1-6). Cambridge: Cambridge University Press.

Baltzly, D., \& Share, M. (Transl.). (2018). Hermias: On Plato Phaedrus 227A-245E. London: Bloomsbury.

Blanshard, A. J. L. (2010). Sex: Vice and Love from Antiquity to Modernity. Malden, MA: Wiley-Blackwell.

Bernabé, A. (Ed.). (2004). Poetae epici graeci: testimonia et fragmenta, II: Orphicorum et orphicis similium testimonia et fragmenta (Fasc. 1). München - Leipzig: K. G. Saur.

Bernard, H. (Ed.). (1997). Hermeias von Alexandrien: Kommentar zu Platons Phaidros. Tübingen: Mohr Siebeck.

Bessarion, B. (1503). In calumniatorem Platonis libri quatuor. Venetiis: in aedibus Aldi Romani.

Bouffartigue, J., Patillon, M., \& Segonds, A. P. (Eds.). (1977-1995). Porphyre. De l'abstinence (3 vols.). Paris: Les Belles Lettres.

Brisson, L., \& Pradeau, J.-F. (Transl.). (2006). Platon. Les lois. Livres I à VI. Livres VII à XII. (Vol. 2). Paris: Flammarion.

Burnet, J. (Ed.). (1900-1907). Platonis Opera (5 vols.). Oxford: Clarendon Press.

Couvreur, P. (Ed.). (1901). Hermiae Alexandrini in Platonis Phaedrum scholia. Paris: Bouillon.

Creed, J. L. (Ed.). (1984). Lactantius: De mortibus persecutorum. Oxford: Clarendon Press.

Des Places, E. (Ed.). (1971). Oracles chaldaïques: avec un choix de commentaires anciens. Paris: Les Belles Lettres.

Des Places, E. (Ed.). (1982). Porphyre. Vie de Pythagore; Lettre à Marcella. Paris: Les Belles Lettres.

Diels, H., \& Kranz, W. (Eds.). (1951). Die Fragmente der Vorsokratiker: griechisch und deutsch (DK) (Vol. 1). Berlin: Weidmann.

Dillon, J. (1994). A Platonist Ars Amatoria. Classical Quarterly, 44(2), 387-392.

Dover, K. J. (1979). Greek Homosexuality. London: Duckworth.

Duffy, J. M., Sheridan, P. F., Westerink, L. G., \& White, J. A. (Eds.). (1969). Porphyry, The Cave of the Nymphs in the Odyssey. Buffalo: Department of Classics, State University of New York at Buffalo. Fortier, S. (2018). The Nature of the Scholia on Plato's Phaedrus. Phronesis, 63(4), 449-476.

Gerson, L. P. (Transl.). (2017). Plotinus: The Enneads. Cambridge: Cambridge University Press. 
Giavatto, A. (2019). Notes sur le $\S 13-19$. In T. Dorandi (Ed.), Porphyre. L'Antre des nymphes dans l'Odyssée (pp. 200-210). Paris: Vrin.

Goulet, R. (2004). Hypothèses récentes sur le traité de Porphyre Contre les Chrétiens. In M. Narcy, \& E. Rebillard (Eds.), Hellénisme et christianisme (pp. 61-109). Villeneuve d'Ascq: Presses universitaires du Septentrion.

Goulet, R. (2016). Théosébios. In R. Goulet (Ed.), Dictionnaire des philosophes antiques, VI: De Sabinillus à Tyrsénos (pp. 1128-1129). Paris: CNRS.

Hadot, I. (2015). Athenian and Alexandrian Neoplatonism and the Harmonization of Aristotle and Plato (Transl. M. Chase). Leiden - Boston: Brill.

Hadot, P. (1968). Porphyre et Victorinus (Vol. 1). Paris: Études augustiniennes.

Hadot, P. (Transl.). (1990). Plotin, Traité 50: [Ennéades] III, 5. Paris: Cerf.

Henry, R. (1959-1974) (Ed.). Photius, Bibliothèque (Vols I-VII). Paris: Les Belles Lettres.

Henry, P., \& Schwyzer, H.-R. (Eds.). (1964-1982). Plotini Opera (3 vols.). Oxford: Clarendon Press. Igal, J. (Transl.). (1985). Plotino: Enéadas III-IV. Madrid: Gredos.

Isaac, D. (Ed.). (1982). Proclus: Trois études sur la providence, III: De l'existence du mal. Paris: Les Belles Lettres.

Kern, O. (Ed.). (1922). Orphicorum fragmenta. Berlin: Weidmann.

Kremer, K. (1987). Bonum est diffusivum sui. Ein Beitrag zum Verhältnis von Neuplatonismus und Christentum. In W. Haase (Ed.), Aufstieg und Niedergang der römischen Welt (Vol. 36.2; pp. 9941032). Berlin - New York: De Gruyter.

Kroll, W. (Ed.). (1899-1901). Procli Diadochi in Platonis rem publicam commentarii (2 vols.). Leipzig: Teubner.

Lamberton, R. (Transl.). (1983). Porphyry. On the Cave of the Nymphs. Barrytown, NY: Station Hill Press.

Lamberz, E. (Ed.). (1975). Porphyrii Sententiae ad intelligibilia ducentes. Leipzig: Teubner.

Louis, P. (Ed.). (1964). Aristote. Histoire des animaux, I: Livres I-IV. Paris: Les Belles Lettres.

LSJ = Liddell, H. G., Scott, R., \& Jones, H. S. (1996). A Greek-English Lexicon (with a revised supplement). Oxford: Clarendon Press.

Lucarini, C. M., \& Moreschini, C. (Eds.). (2013). Hermias Alexandrinus: In Platonis Phaedrum Scholia. Berlin: De Gruyter.

Marcovich, M. (Ed.). (1967). Heraclitus: Greek Text with a Short Commentary. Mérida: The Los Andes University Press.

Moreschini, C. (2017). Le démon de Socrate et son langage dans la philosophie médioplatonicienne. In L. Soares Santoprete, \& P. Hoffmann (Eds.), Langage des dieux, langage des démons, langage des hommes dans l'Antiquité (pp. 121-135). Turnhout: Brepols.

Morvan, T. (2013). Érôs et le lien cosmique: lecture ancienne et nouvelle du Banquet de Platon. Paris: L'Harmattan.

Nauck, A. (Ed.). (1886). Porphyrii philosophi Platonici opuscula selecta. Leipzig: Teubner.

O’Meara, D. J. (1993). Aspects of Political Philosophy in Iamblichus. In H. J. Blumenthal, \& E. G. Clark (Eds.), The Divine Iamblichus: Philosopher and Man of Gods (pp. 65-73). London: Bristol Classical Press.

O’Meara, D. J. (2003). Sur les traces de l'absolu: études de philosophie antique. Fribourg - Paris: Academic Press Fribourg - Cerf. 
O’Neill, W. (Transl.). (1971). Proclus: Alcibiades I. The Hague: Martinus Nijhoff.

Roskam, G. (2014). Socratic Love in Neoplatonism. In D. A. Layne, \& H. Tarrant (Eds.), The Neoplatonic Socrates (pp. 21-35). Philadelphia: University of Pennsylvania Press.

Saffrey, H. D., \& Westerink, L. G. (Eds.). (1968-1997). Proclus: Théologie platonicienne (6 vols.). Paris: Les Belles Lettres.

Segonds, A. P. (Ed.). (1985-1986). Proclus: Sur le premier Alcibiade de Platon (2 vols.). Paris: Les Belles Lettres.

Simonini, L. (Transl.). (1986). Porfirio, L'antro delle Ninfe. Milano: Adelphi.

Van der Meeren, S. (2017). L' 'entretien' philosophique d'après le commentaire de Proclus au Premier Alcibiade de Platon. In L. G. Soares Santoprete, \& P. Hoffmann (Eds.), Langage des dieux, langage des démons, langage des hommes dans l'Antiquité (pp. 231-262). Turnhout: Brepols.

Van Riel, G., Macé, C., \& Follon, J. (Eds.). (2008). Damascius. Commentaire sur le Philèbe de Platon. Paris: Les Belles Lettres.

Westerink, L. G. (Ed.). (1954). Proclus Diadochus. Commentary on the first Alcibiades of Plato. Amsterdam: North-Holland.

Westerink, L. G. (Ed.). (1956). Olympiodorus. Commentary on the First Alcibiades of Plato. Amsterdam: North-Holland.

Westerink, L. G. (Ed.). (1970). Olympiodorus. In Platonis Gorgiam Commentaria. Leipzig: Teubner.

Westerink, L. G., Trouillard, J., \& Segonds, A. P. (Eds.). (1990). Prolégomènes à la philosophie de Platon. Paris: Les Belles Lettres.

Wolters, A. M. (1972). Plotinus on Eros: a Detailed Exegetical Study of Enneads III, 5. Amsterdam: Vrije Universiteit te Amsterdam.

Zamora Calvo, J. M. (2016). El primer principio, 'potencia de todas las cosas', en Plotino. Endoxa, 38 , 131-144 [online available at https://doi.org/10.5944/endoxa.38.2016.16596].

Zintzen, C. (Ed.). (1967). Damascii Vitae Isidori reliquiae edidit annotationibusque instruxit. Hildesheim: Olms.

\section{Prof. José María Zamora Calvo / jm.zamora@uam.es}

Department of Philosophy

Autonomous University of Madrid, Faculty of Philosophy and Arts

Campus de Cantoblanco, 28049 Madrid, Spain 
